Bolm Inst. oceanogr., S Paulo, 33(2):201-212, 1985

\title{
NOTES ON ELECTROPHEROGRAMS OF EYE-LENS, MUSCLE PROTEINS AND ZYMOGRAMS OF MUSCLE ESTERASES OF FISH COLLECTED DURING THE FIRST BRAZILIAN EXPEDITION TO THE ANTARCTICA
}

PHAN Van Ngan; Hana SUZUKI*; Vicente GOMES* \& Maria Josē de Arruda Campos Rocha PASSOS**

Instituto Oceanogräfico da Universidade de São Paulo (Caixa Postal, 9075, 01000 São Paulo, SP)

\section{Synopsis}

A preliminary study was carried out on electropherograms of eye-lens, muscie proteins and zymogroms of muscle esterases of ten Notothenia larseni, six Notothenia nudifrons and one Zanternfish, Electrona antarctica. The fish were collected by the $R / V$ "Prof. W. Besnard" of the Institute of Oceanography, University of São Paulo, during the First Brazilian Expedition to Antaratica. Eye-lens proteins were analysed on cellulose acetate membrane, muscle proteins and esterases on gel of polyacrylamide. Eye-lens proteins showed three types of electropherograms for $N$. larseni and two types for $N$. nudifrons. One of the electropherograms of $N$. larseni can be readily distinguished from those of $N$. nudifrons. Electropherograms of musale proteins of $N$. larseni and $N$. nudifrons are very similar and consist of sixteen to seventeen fractions. Electropherogroms of muscle proteins of $N$. larseni are severely affected by the conservation of the extracts overnight under $-20^{\circ} \mathrm{C}$. AlZ N. nudifrons were of the same zymograms of esterases while those of $N$. larseni varied. Electropherograms of eye-lens and muscle proteins as well as zymograms of esterases of the lanternfish are different from those of nototheniids.

Descriptors: Marine fishes, Electrophoresis, Esterases, Proteins, Muscle, Eye-lens, Notothenia larseni, Notothenia nudifrons, Electrona antarctica, R/V "Prof. W. Besnard", Bransfield Strait, Antarctica.

Descritores: Peixes marinhos, Eletroforese, Esterases, Proteínas, Müsculo, Cristalino, Notothenia larseni, Notothenia nudifrons, Electrona antarctica, N/Oc. "Prof. W. Besnard", Estreito de Bransfield, Antärtica.

\section{Introduction}

Electrophoretic techniques and histochemical staining methods (Smithies, 1959; Hunter \& Markert, 1957) have been widely used for studies of genetic variation in species (Ayala, 1976; Selander \& Johnson, 1973). In many areas of the world's seas, the fish

(*) Graduate Student, Institute of Oceanography, Departament of Biological Oceanography, Fellow of CNPq .

(**) CIRM - IOUSP

Publ. n. 637 do Inst. oceanogr. da Usp. fauna has been a subject of this kind of investigation (de Ligny, 1969; 1972) but there is very few information in this field on fish of the region south of the Antarctic Convergence.

During the First Brazilian Expedition to Antarctica, a small number of fish belonging to several species was caught in experimental fishing with drag net and Isaacs-Kidd mid-water trawl realized by the research vessel "Prof. W. Besnard" of the Institute of Oceanography, University of São Paulo. Eye-1ens and muscle samples of some os these fish were collected for this preliminary study in order to gather information on techniques of analysis and on the 
possible use of these samples for more detailed investigations in the future.

\section{Material and methods}

Materials used in this study were eye-lenses and muscle samples of ten Notothenia larseni (Lonnberg, 1905), six $N$. nudifrons (Lonnberg, 1905) of the family Nototheniidae and one lanternfish Electrona antarctica (Gunther, 1878) of the family Myctophidae. Sexes of the fishes were unknown. The nototheniids, ranging from 129 to $158 \mathrm{~mm}$ in total length, were caught by the drag net at station no. $24\left(062^{\circ} 43^{\prime} .0 \mathrm{~s} ; 054^{\circ} 24^{\prime} .0 \mathrm{~W}\right)$ and the lanternfish, $80 \mathrm{~mm}$ in total lenght, was caught by Isaacs-Kidd mid-water trawl at station no. 25 $\left(062^{\circ} 25^{\prime} .0 \mathrm{~S}\right.$; $\left.054^{\circ} 24^{\prime} .0 \mathrm{~W}\right)$ in the Bransfield Strait, Austral Summer 1982-1983.

Eye-1enses and muscle samples were collected from alive specimens on board of the vessel and kept in the freezer at $-20^{\circ} \mathrm{C}$ until use. Eye-lenses were macerated in solution of $0.9 \% \mathrm{NaCl}$ by means of an electric homogenizer. Two proportions, namely $1: 2$ and $1: 4$ (tissue weight/volume of extraction fluid) were tested. The extracts were centrifuged at $3500 \mathrm{rpm}$ for $30 \mathrm{~min}$. Muscles were macerated in solution of glycerin-EDTA-Tris $\mathrm{pH} 8.7$ (Scopes, 1968) in the proportion of $1: 2$ (weight/volume). Macerated material were spun at $3500 \mathrm{rpm}$ for $15 \mathrm{~min}$, supernatants were collected and submitted again to another

centrifugation at $10000 \mathrm{rpm}$ for $15 \mathrm{~min}$. Total protein contents were determined by Biuret method (Gornall et al., 1949). Eye-lens proteins were analysed by electrophoresis on cellulose acetate membranes (Cellogel, Chemetron, $5.7 \times 14 \mathrm{~cm})$. Two systems of buffers, Tris-g1ycine $\mathrm{pH} 8.3$ and Tris-glycine $\mathrm{pH} 9.5$ were tested. Electrophoresis was performed at $300 \mathrm{~V}$ across the membrane during $25 \mathrm{~min}$. Origin was at $1.5 \mathrm{~cm}$ from the cathode. Electropherograms were visualized by Ponceau S.

Densitometric readings were taken on an Atago densitometer using filter of $500 \mathrm{~nm}$. Muscle proteins were analysed by vertical polyacrylamide flat gel electrophoresis. The method used was a modification of the method by Akroyd (1967) as described by Phan (1980). The membrane consists of two layers of gels of different concentrations in different buffers (Brewer et al., 1974). Tris-Glycine buffer adjusted to $\mathrm{pH} 8.9$ with $1 \mathrm{~N} \mathrm{NaOH}$ was used as electrode buffer. For general proteins analysis, $5 \mu 1$, and for esterases, $40 \mu 1$ of extract containing $10 \%$ of saccharose were used. Electrophoresis was carried out, passing firstly by a current of $20 \mathrm{~mA}$ for about $5 \mathrm{~min}$ until the Bromophenol Blue used as tracer reached the interface of the upper and the lower gel then passing a current of $45 \mathrm{~mA}$ for about $30 \mathrm{~min}$ for the analysis in the lower gel until the tracer dye reached the determined point. Electropherograms of muscle proteins were visualized by Coomassie Blue. Zymograms of esterases were obtained by the modified techniques of Gomori as described by Flowerdew \& Crisp (1975).

\section{Results}

The proportion between weight of eye-lenses and volume of extraction fluid is important for the quality of the electropherograms of eye-1ens proteins. Under the same conditions extracts obtained by homogenizing eye-1ens in the proportion $1: 2$

(weight/volume) resulted in electropherograms with fractions sharper than those obtained with samples homogenized in the proportion $1: 4$. Total protein concentrations were $8.71 \pm 1.80 \mathrm{~g} / \mathrm{d} 1 \quad(\mathrm{n}=8)$ and $5.82 \pm 0.47$ $\mathrm{g} / \mathrm{d} 1(\mathrm{n}=8)$ for extracts obtained by homogenizing in the proportion of $1: 2$ and $1: 4$ respectively. Electrophoresis of the same samples realized with Tris-glycine $\mathrm{pH} 8.3$ and Tris-Glycine $\mathrm{pH} 9.5$ buffers resulted in electropherograms of the same number of fractions. Electropherograms obtained with Tris-glycine $\mathrm{pH}$ 9.5, however, showed sharper separation and higher migration of fractions, specially the cathodic ones (Fig. 1). Electropherograms of $N$. larseni comprised from ten to eleven fractions and those of $N$. nudifrons from nine to ten fractions. The fractions were denominated sucessively by alphabetic letters. Two consecutive or twin fractions may be classified as a complex (Figs 2-3). Three types of electropherograms of eye-1ens proteins of N. larseni were recognized. They were denominated Type-I (larseni), Type-II (1arseni) and Type-III (1 arseni). Type-I (1 arseni) differs from Type-II 


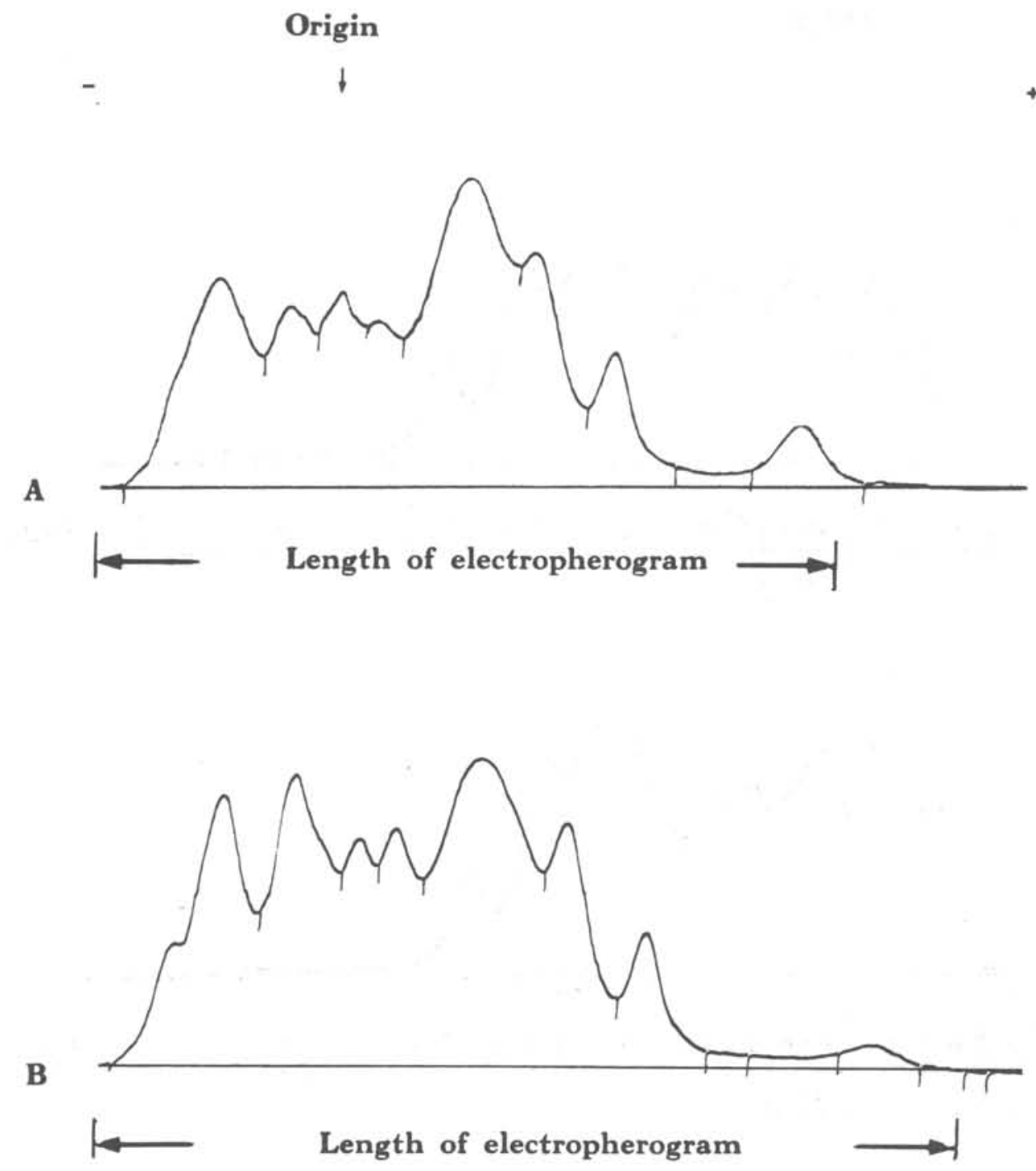

Fig. 1. Densitometric curves of the electropherograms of eye-lens proteins of the same $N$. larseni obtained in cellulose acetate membrane with different buffers.

A. Tris-Glycine pH 8.3 buffer

B. Tris-Glycine pH 9.5 buffer

(1arseni) and Type-III (1arseni) by the Complex-II. In Type-I (larseni) this complex is made up by two separate fractions "d" and "e" while in Type-II (1arseni) and Type-III (1arseni) it is made up by two twin fractions "d+e". Type-II (larseni) differs from Type-I (larseni) and Type-III (1arseni) by the fraction "a". In electropherograms this fraction appears as a weak stain at the cathode side and in densitometric curves as a tail of fraction "b" (Fig. 2). Relative concentration of this fraction, whenever possible, was computed together with that of fraction "b" as relative concentration of Complex-I. Of the ten examined $N$. larseni eight were Type-I ( 1 arseni), one was Type-II (1 arseni) and one Type-III (1arseni).

Two types of electropherograms of eye-lens proteins of $N$. nudifrons, namely Type-I (nudifrons) and Type-II (nudifrons), can be recognized. These types differ from each other by fraction "a" (Fig. 3). Two out of the six N. nudifrons examined were Type-I

(nudifrons); the other four were Type-II (nudifrons). Electropherograms of 


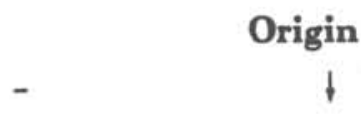

Fraction

Complex

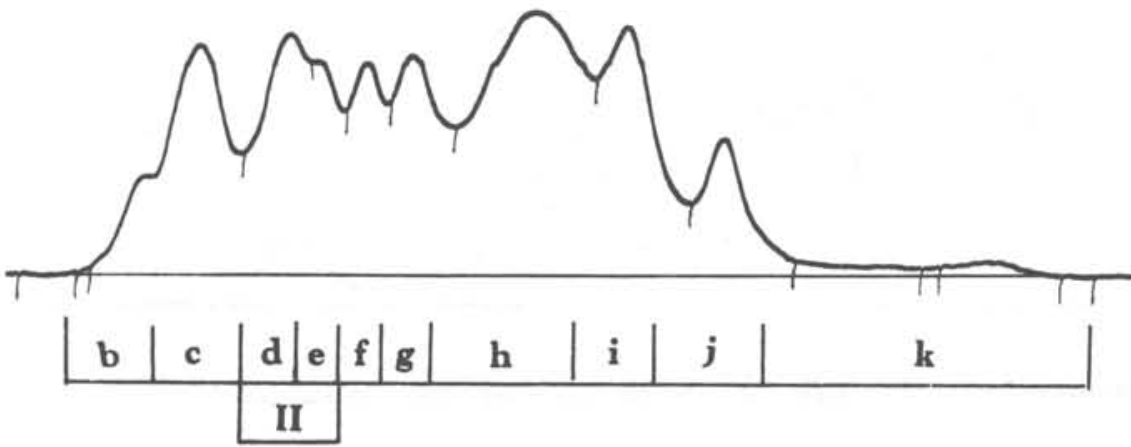

Type I(larseni)

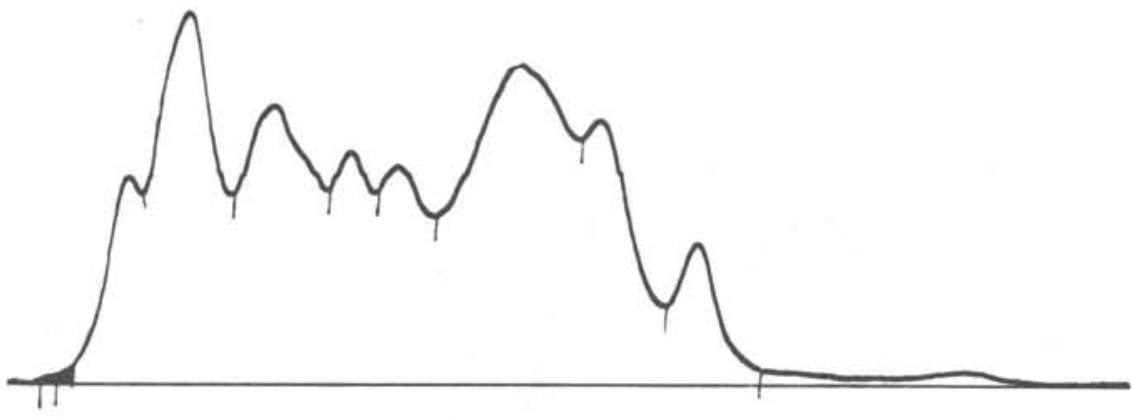

Fraction

Complex

\begin{tabular}{|c|c|c|c|c|c|c|c|c|c|}
$\mathbf{a}$ & $\mathbf{b}$ & $\mathbf{c}$ & $\mathbf{d}+\mathbf{e}$ & $\mathbf{f}$ & $\mathbf{g}$ & $\mathbf{h}$ & $\mathbf{i}$ & $\mathbf{j}$ & $\mathbf{k}$ \\
\hline \multicolumn{2}{|c|}{ I } & \multicolumn{4}{|l}{ II } & &
\end{tabular}

Type II (larseni)

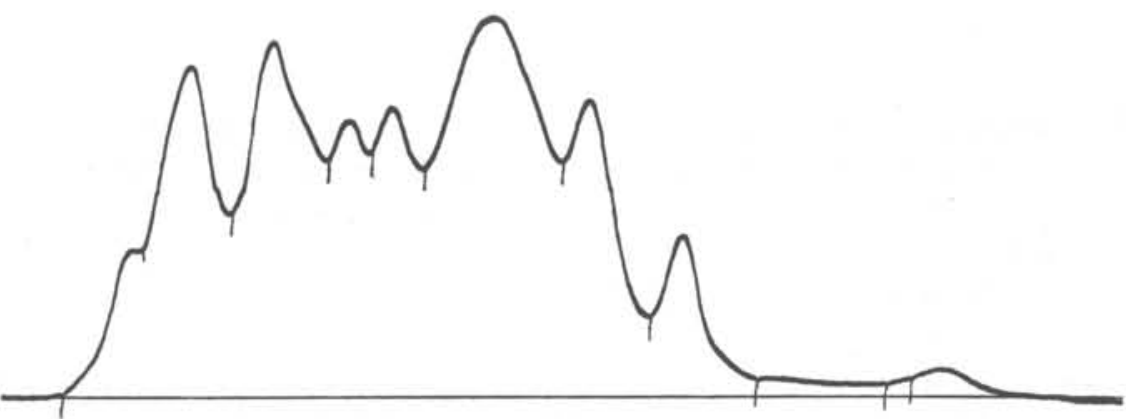

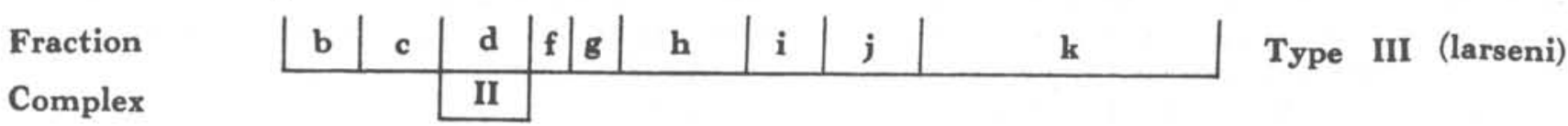

Fig. 2. Densitometric curves of three different types of electropherograms of eye-lens proteins of $N$. larseni and denominations of their fractions and complexes.

Type I (larseni) without "a"; "d" and "e" separate.

Type II (larseni) with "a"; "d" and "e" twin.

Type III (larseni) without "a "; "d" and "e" twin. 


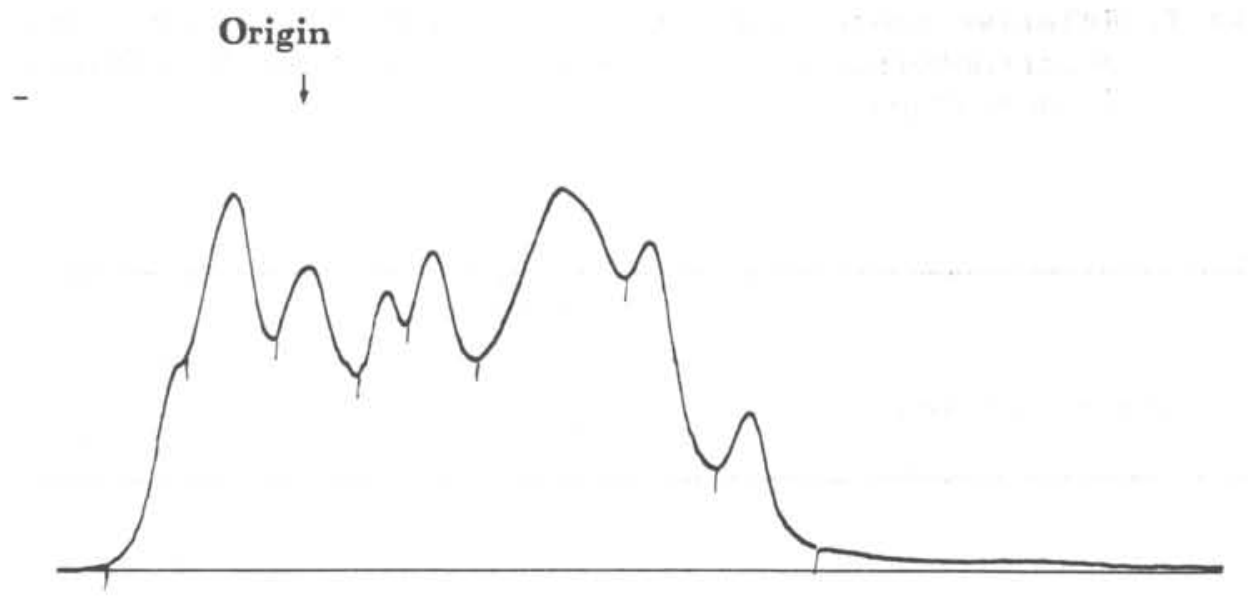

Fraction

\begin{tabular}{|l|l|l|l|l|l|l|l|l|}
$\mathbf{b}$ & $\mathbf{c}$ & $\mathbf{d}$ & $\mathbf{f}$ & $\mathbf{g}$ & $\mathbf{h}$ & $\mathrm{i}$ & $\mathbf{j}$ & $\mathbf{k}$ \\
\hline
\end{tabular}

Type I (nudifrons)

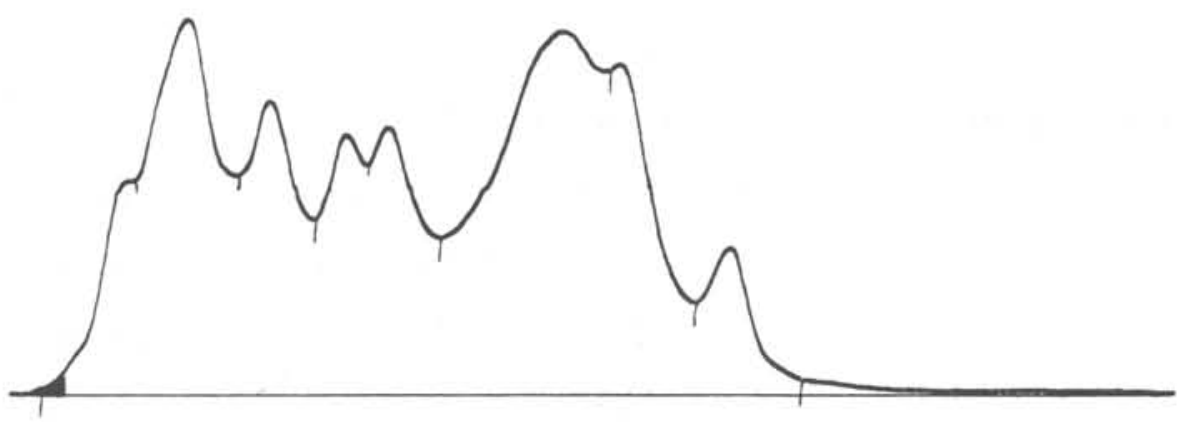

\begin{tabular}{l|l|l|l|l|l|l|l|l|l|l|l|} 
Fraction & a & b & c & d & f & g & h & i & j & k \\
\cline { 2 - 7 } Complex & I & \multicolumn{10}{|l}{}
\end{tabular}

Type II (nudifrons)

Fig. 3. Densitometric curves of two different types of electropherograms of eye-lens proteins of $N$. nudifrons and denominations of their fractions and complex.

Type I (nudifrons) without "a"; "e" absent.

Type II (nudifrons) with "a"; "e" absent.

eye-lens proteins of $N$. larseni and $N$. nudifrons differ qualitatively and quantitatively. Qualitatively electropherograms of eye-lens proteins of both fish differ by the Complex II. In N. larseni, this complex consists of two separate or twin fractions "d" and "e"; in N. nudifrons, however, in the position of this complex, there is only fraction "d" (Figs 2-3).

Electropherograms of $1:$. larseni and N. nudifrons also differ by fraction " $k$ " which in $N$. larseni appeared as a small peak at the mode extremity of densitometric curves (Fig. 3). Quantitatively, both species differ by the relative concentration of fraction "c" which is significantly higher in N. nudifrons (Table 1 ).

Electropherograms of muscle proteins of $N$. larseni and N. nudifrons are very similar. Qualitatively, only a slight difference in sharpness of several fine and faint fractions in the cathode side of electropherograms can be recognized (Fig. 4).

Densitometric curves of electropherograms of muscle proteins of $N$. larseni and $N$. nudifrons showed sixteen to seventeen fractions. They were denominated sucessively by arabic numbers from cathode to anode (Fig. 5). 
Table 1. Relative concentrations (\%) of fractions and complexes of electropherograms of eye-lens proteins of $N$. larseni and

N. nudifrons

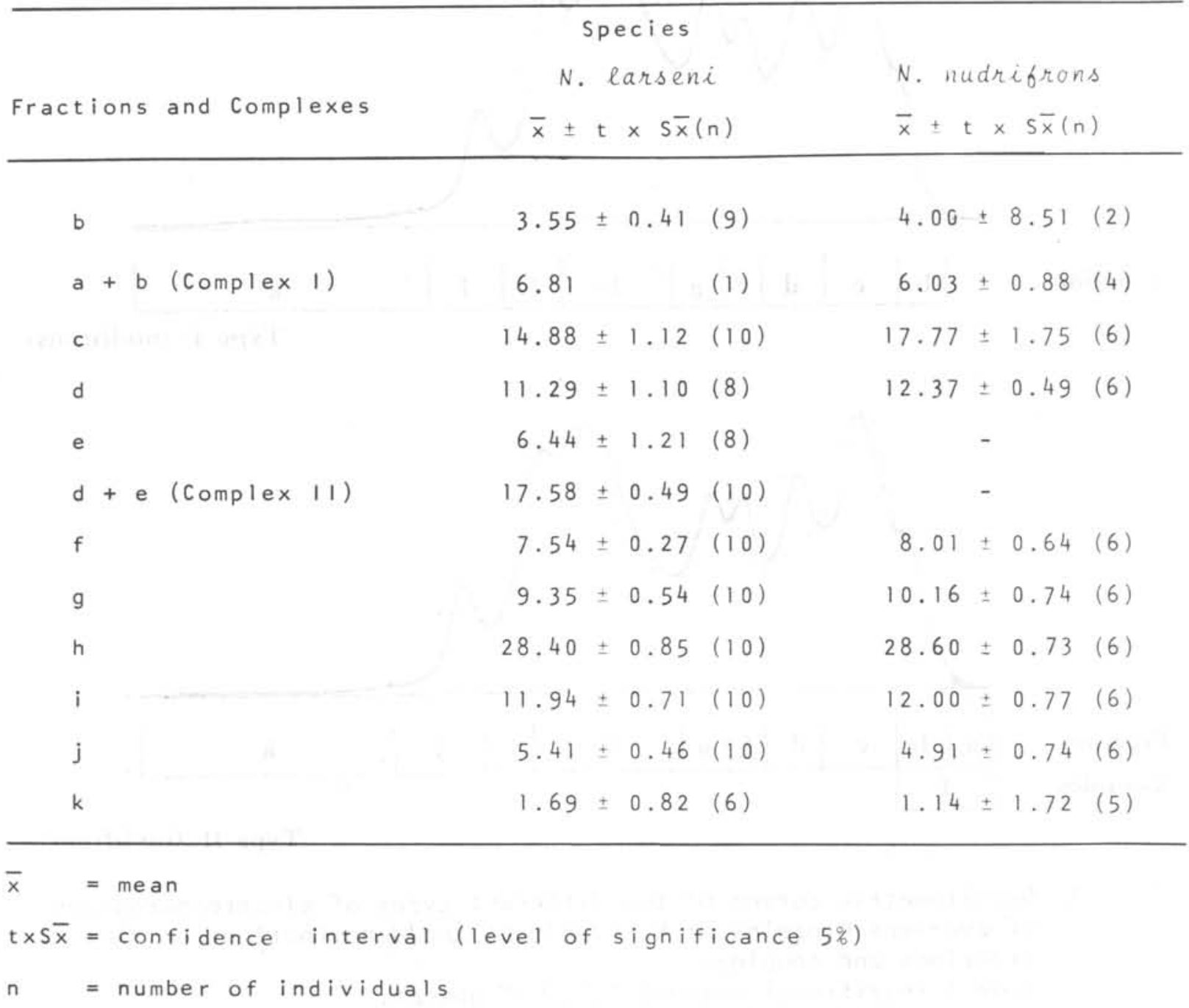

Quantitatively, only the difference in relative concentration of fraction "11" of both species is significant (Table 2).

Extracts of three $N$. larseni were kept overnight at $-20^{\circ} \mathrm{C}$ and their electropherograms were compared with those obtained before the conservation. It was noticed that the conservation affected not only the number but also the migration of the fractions. Fraction "14" was divided into "14a" and "14b"; fraction "18" a new and faint fraction, appeared near the anode of electropherograms of conserved extracts. Migration velocities of various fractions, especially those of fractions
"11" onward, become more rapid than their correspondents before the conservation (Fig. 5).

Zymograms of muscle esterases are shown in Figure 6. All N. nudifrons are of the same zymograms while those of $N$. larseni varied. Four out of the ten N. larseni showed the same zymograms as those of $N$. nudifrons. Apparently zymograms of muscle esterases were not affected by the conservation of extracts.

Electropherograms of eye-lens, muscle proteins and zymograms of muscle esterases of the lanternfish are distinctly different from those of nototheniids (Figs 4, 6, 7). 


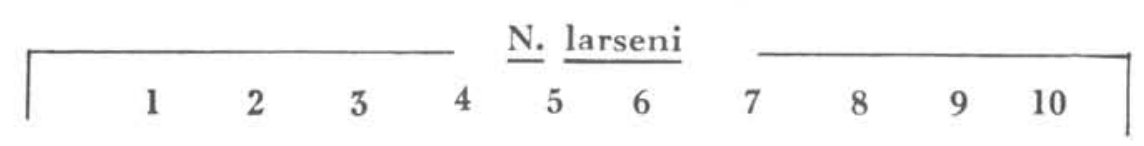

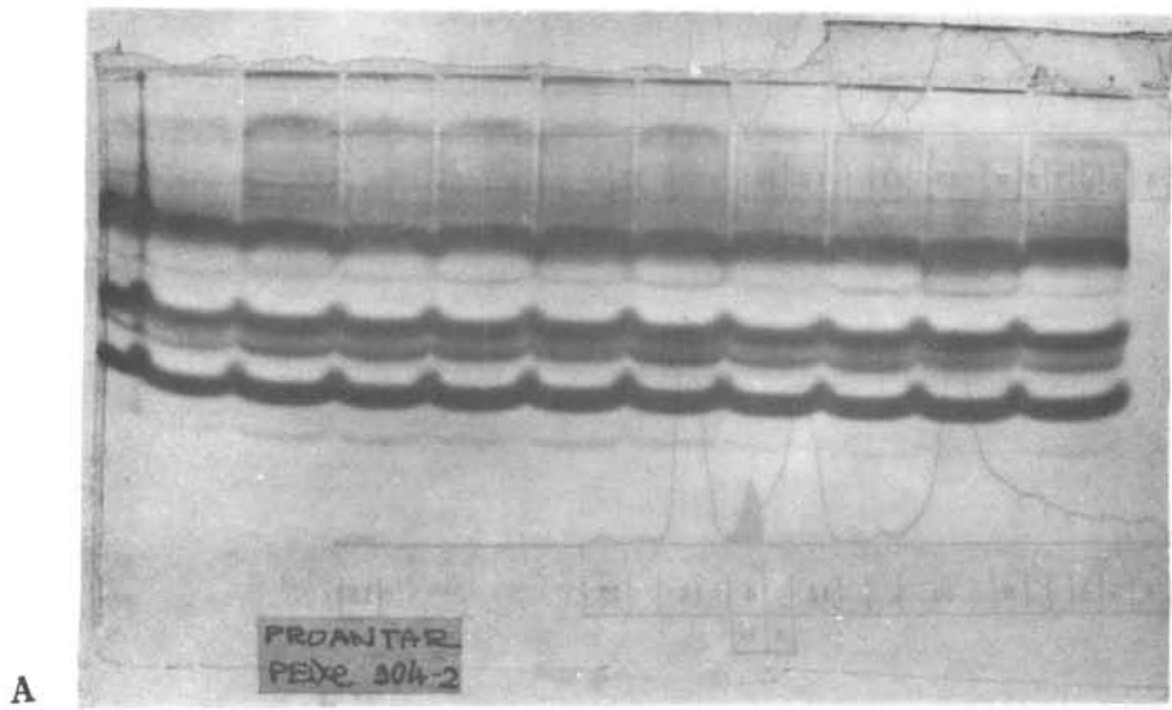

\section{$\longleftarrow$ Origin}

Interface of upper and lower gels

Lanternfish
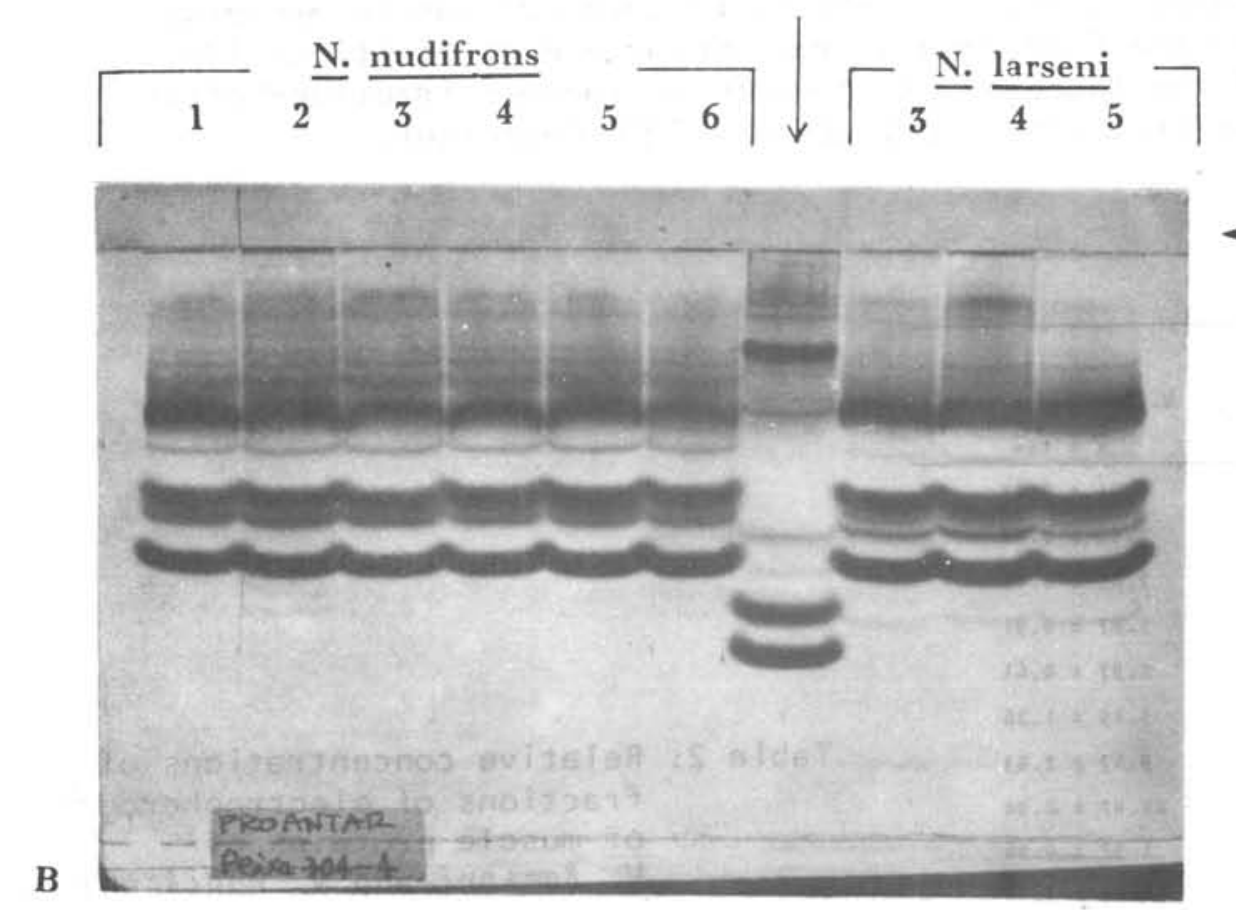

Interface of upper and lower gels

Fig. 4. Electropherograms of muscle proteins of Antarctic fish obtained in gel of polyacrylamide.

A. Ten N. larseni (individual number from 1 to 10 ).

B. Six N. nudrifrons (individual number from 1 to 6 ). the lanternfish and repetitions of extracts of $N$ : larseni number 3,4 and 5 after their conservation at $-20^{\circ} \mathrm{C}$ overnight. 
Origin

1
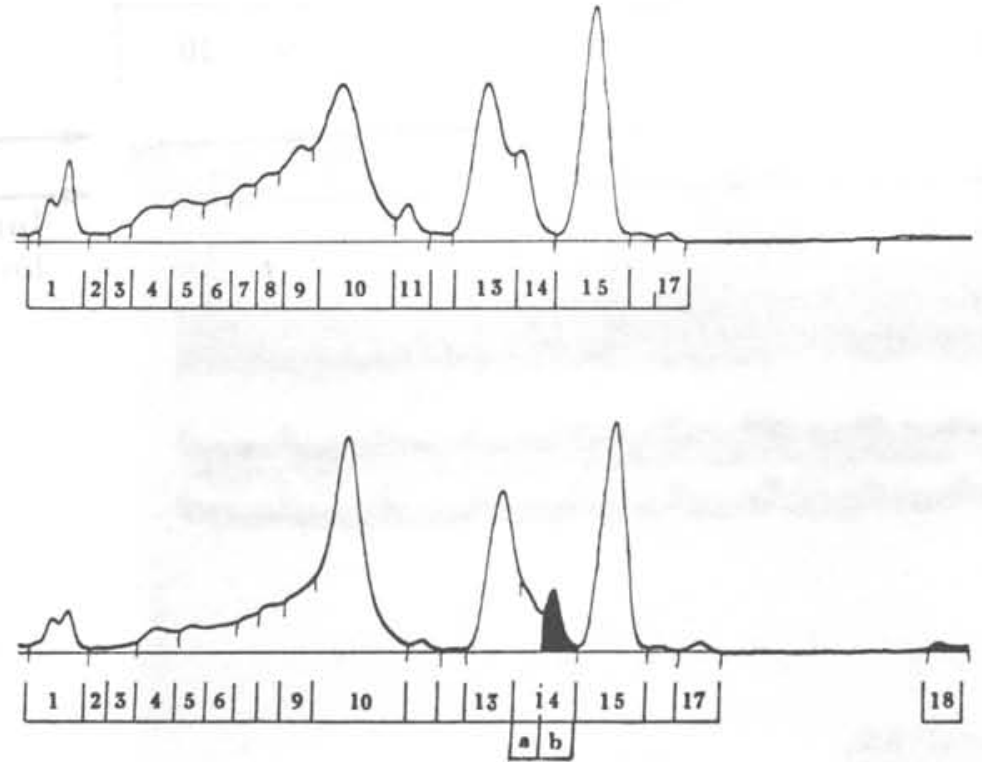

Fig. 5. A. Densitometric curve of electropherogram of muscle proteins of $N$. larseni and denomination of fractions.

B. Densitometric curve of electroferogram of muscle proteins of the same fish showing the appearance of fractions 14b, 18 and the increase of velocity of various fractions after the conservation of extract at $-20^{\circ} \mathrm{C}$ overnight.

\begin{tabular}{|c|c|c|}
\hline \multirow[b]{2}{*}{ Fraction } & \multicolumn{2}{|l|}{ Species } \\
\hline & $\begin{array}{c}\text { N. Larseni }(n-10) \\
\bar{x} \pm t s \bar{x}\end{array}$ & $\begin{array}{l}\text { N. nudifrons }(n-6) \\
\bar{x} \pm t 5 \bar{x}\end{array}$ \\
\hline 1 & $3.13 \pm 1.59$ & $1.51 \pm 0.83$ \\
\hline $2+3+4$ & $2.43 \pm 0.65$ & $2.06 \pm 0.88$ \\
\hline 5 & $1.47 \pm 0.39$ & $2.09 \pm 0.87$ \\
\hline 6 & $1.68 \pm 0.44$ & $1.87 \pm 0.91$ \\
\hline 7 & $2.02 \pm 0.41$ & $2.97 \pm 0.61$ \\
\hline 8 & $4.22 \pm 0.74$ & $5.15 \pm 1.26$ \\
\hline 9 & $6.49 \pm 1.24$ & $9.47 \pm 2.03$ \\
\hline 10 & $27.83 \pm 2.66$ & $25.07 \pm 2.90$ \\
\hline 11 & $1.16 \pm 0.25$ & $1.97 \pm 0.36$ \\
\hline 12 & $0.35 \pm 0.28$ & $0.42 \pm 3.11$ \\
\hline 13 & $19.90 \pm 0.94$ & $19.70 \pm 1.41$ \\
\hline 14 & $7.32 \pm 1.02$ & $6.57 \pm 1.39$ \\
\hline 15 & $21.06 \pm 0.92$ & $20.17 \pm 0.76$ \\
\hline 16 & $0.78 \pm 0.18$ & $0.69 \pm 0.28$ \\
\hline 17 & $1.06 \pm 0.27$ & $0.59 \pm 0.36$ \\
\hline
\end{tabular}

Table 2. Relative concentrations of fractions of electropheragrams of muscle proteins of $N$. larseni and $N$. nudifrons 

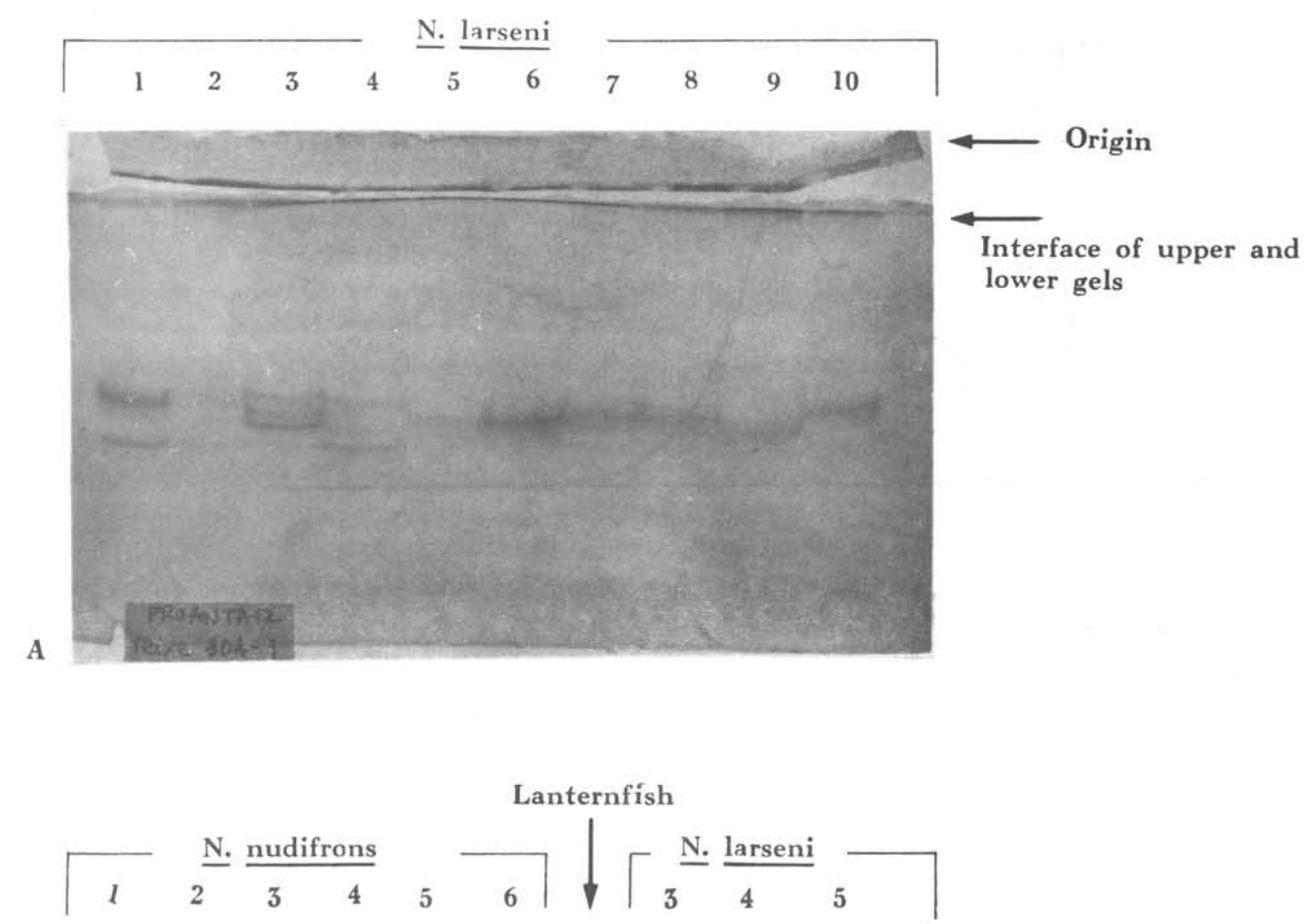

B

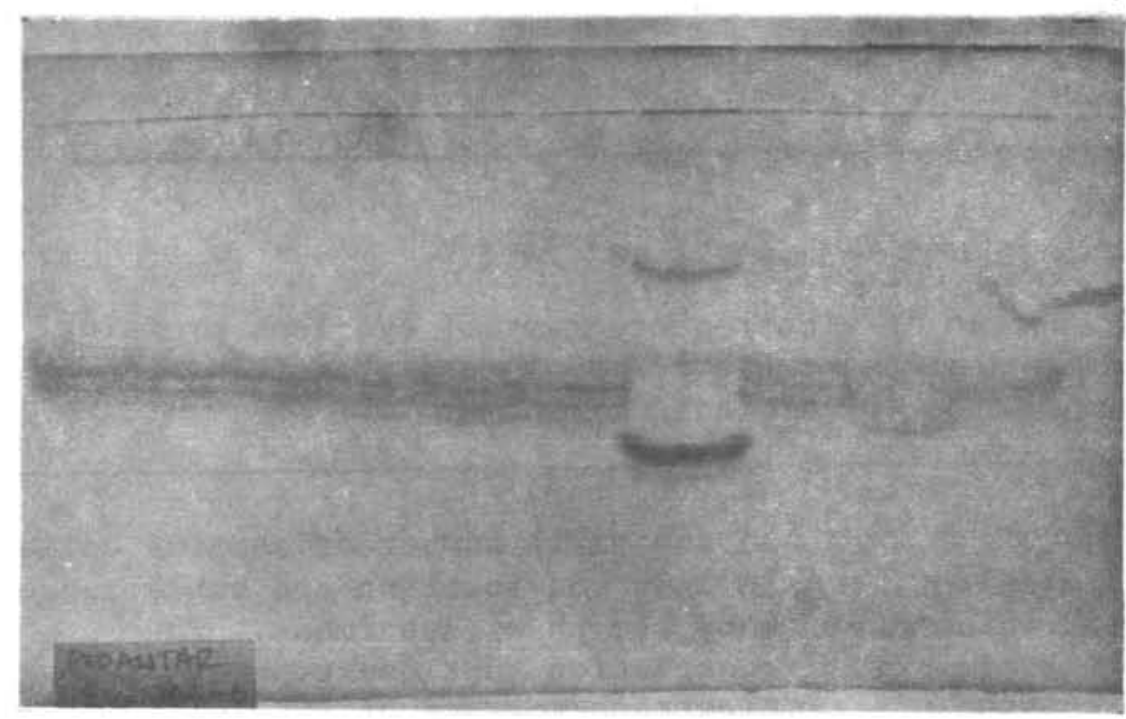

\section{Origin}

Interface of upper and lower gels

Fig. 6. Zymograms of muscle esterases of Antarctic fish obtained in gel of polyacrylamide.

A. Ten N. larseni (individual number from 1 to 10).

B. Six N. nudifrons (individual number from 1 to 6 ); the lanternfish and repetitions of extracts of $N$. larseni number 3,4 and 5 after their conservations at $-20^{\circ} \mathrm{C}$ overnight. 


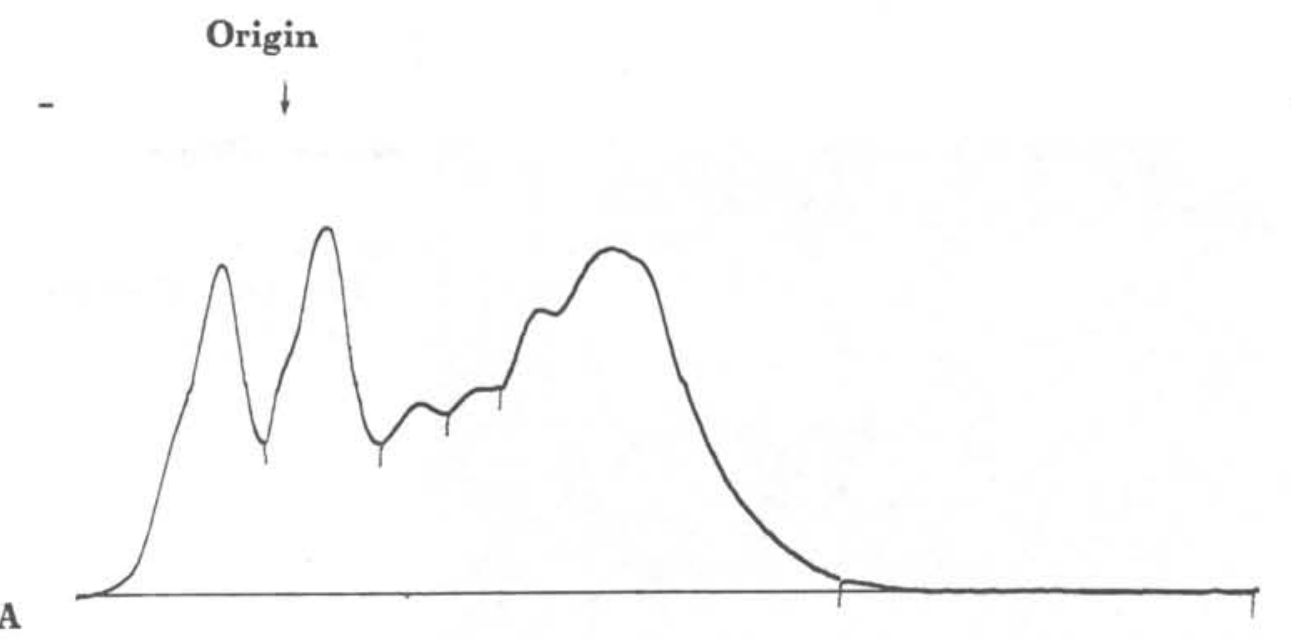

Origin
$-\quad t$

B

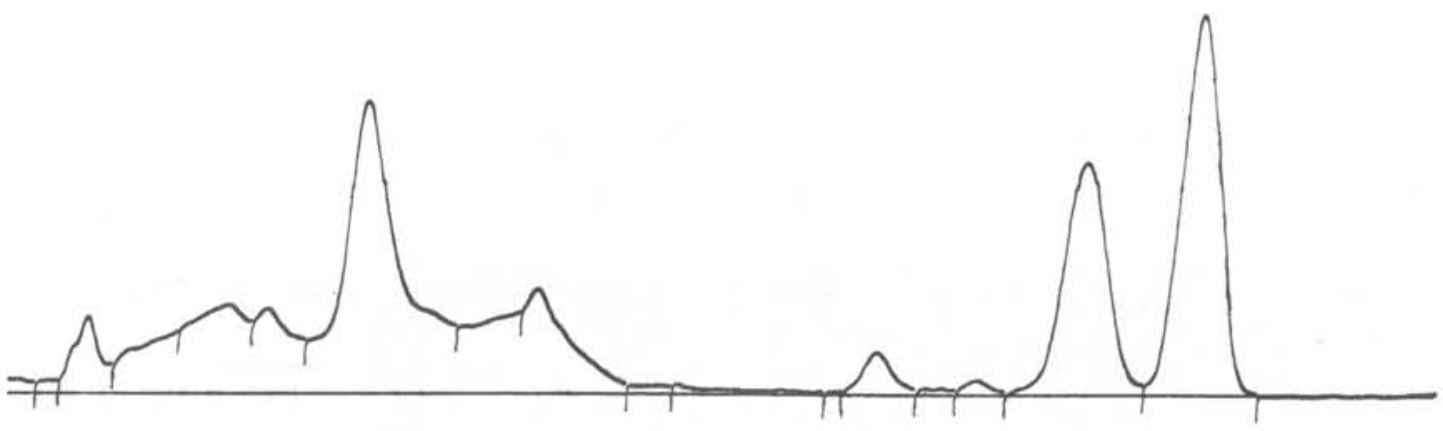

Fig. 7. Densitometric curves of electropherograms of eye-lens proteins (A) in cellulose acetate membrane and of muscle proteins in gel of polyacrylamide (B) of lanternfish.

\section{Discussion and conclusion}

The soluble proteins of the eye-lens were considered to have great value for taxonomic studies because they are synthesized by only one cell type present in the eye as a single layer (0'Rourke, 1974). The use of eye-lens proteins, however, has its drawback because they are known to be affected by ontogenetical and pathological processes (Bon, 1957; Haen \& O'Rourke, 1969; Barrett \& Williams, 1967; Peterson \& Shehadeh, 1971; Phan et al., 1977; Zigman \& Yulo, 1979; Vazzoler \& Phan, 1981). Variation of electropherograms of eye-lens proteins of nototheniids in relation to growth was not studied due to the small number of samples collected in only one location and small range of body length of specimens. The observation that one type of electropherograms of eye-lens proteins of $N$. larseni can be readily

distinguished from those of $N$. nudifrons implied that this tissue might be useful for the identification of species. Soluble muscle proteins of $\mathrm{fish}$ were considered a good material for the study of interspecific variations by means of electrophoretic techniques (Tsuyuki et al., 1965). Conservation of muscle samples of $\mathrm{fish}$ under $-15^{\circ} \mathrm{C}$ for a long period, however, may induce alterations in electropherograms (Moore et al., 1970; 
Suzuki et al., 1983). Electropherograms of muscle proteins of the two nototheniids investigated showed very little intra - and inter-specific differences. Electropherograms of one species were severely affected by the conservation of extracts. Muscle esterases, on the other hand, showed a great degree of intra-specific heterogeneity in $N$. larseni and a high percentage of inter-specific homogeneity between N. larseni and N. nudifrons. These characteristics of muscle esterases coupled with the observation that their zymograms were not affected by conservation of extract make these isozymes a suitable material for the study of protein variations in $N$. larseni and N. nudifrons

\section{Resumo}

Foi realizado um estudo preliminar sobre eletroferogramas de proteínas de cristalino e de músculo esquelético, e zimogramas de esterases de músculo esquelético de dez Notothenia larseni, seis Notothenia nudifrons e de um peixe-1anterna, Electrona antarctica. Os peixes foram coletados pelo N/Oc. "Prof. W. Besnard" do Instituto Oceanográfico da Universidade de São Paulo durante a I Expedição Brasileira à Antártica. As pr teínas do cristalino foram analisadas em membranas de acetato de celulose, enquanto que as proteínas e esterases do músculo esquelético, em gel de poliacrilamida.

As proteínas do cristalino apresentam três tipos distintos de eletroferogramas para N. larseni e dois para N. nudifrons. Um dos eletroferogramas de N. larseni pode ser prontamente distingüido dos de $N$. nudifrons. Eletroferogramas de proteỉnas de músculo de $N$. larseni e de $N$. nudifrons são muito semelhantes e consistem de 16 a 17 frações. Os eletroferogramas de proteínas de músculo de N. larseni são severamente afetados pela preservação dos extratos por uma noite a $-20^{\circ} \mathrm{C}$.

Todos os $\mathrm{N}$. nudifrons apresentam um mesmo zimograma de esterases enquanto que os de $N$. larseni variam.

Tanto os eletroferogramas de proteínas do cristalino e do músculo como os zimogramas de esterases do peixe-lanterna são diferentes dos apresentados pelos nototeniídeos.

\section{Acknowledgements}

The authors wish to express their thanks to Dr Adolf Kellermann, Institut fur Polarökologie der Christian-Albrechts Universität, and Mr. Uwe Rowedder, Küsten und Binnenfischerei, Kiel, West Germany, for identification of the nototheniids and the lanternfish, respectively. The authors wish also to thank Dr Renato Amaral, Universidade Federal do Rio Grande do Sul, Brazil, for his excellent assistance in sampling during the Expedition, and to Mrs Maria Cecilia Catunda for polishing the English in the manuscript.

\section{References}

AKROYD, P. 1967. Acrylamide gel slab: electrophoresis in a simple glass cell for improved resolution and comparison of serum protein. Analytical Biochem., 19:399-410.

AYALA, F. J., ed. 1976. Molecular evolution. Sunderland, Mass., Sinauer Associates, 277p.

BARRETT, I. \& WILLIAMS, A. A. 1967. Soluble lens proteins of some scombroid fishes. Copeia, (2):468-471.

BON, W. F. 1957. Some physico-chemical data about the ontogenetic and phylogenetic development of the eye lens proteins of fish. Pubbl. Staz. Zoo1. Napoli, $30(3): 373-380$.

BREWER, J. M.; PESCE, A. J. \& ASHWORTH, R. B. 1974. Experimental techniques in biochemistry. New Jersey, Prentice-Hal1, p. 351.

De LIGNY, W. 1969. Serological and biochemical studies on fish populations. Oceanogr. Mar. Biol. Ann. Rev., 7:411-513.

\section{Blood and} biochemical polymorphism in fishes. In: European Conference on Animal Blood Groups and Biochemical Polymorphisms:12. The Hague, Dr. W. Junk, p.55-65.

FLOWERDEW, M. W. \& CRISP, D. J. 1975. Esterase heterogeneity and an investigation into racial differences 
in the cirriped Balanus balanoides using acrylamide gel electrophoresis. Mar. Bio1., 33:33-39.

GORNALL, A. C.; BARDAWILL, C. S. \& DAVID, M. M. 1949. Determination of serum proteins by means of biuret reaction. J. biol. Chem., 177:751766.

HAEN, P. J. \& O'ROURKE, F. J. 1969. Comparative electrophoretic studies on soluble eyelens proteins of some Irish freshwater fishes. Proc. R. Ir. Acad., 68 (B4):67-75.

HUNTER, R. L. \& MARKERT, C. L. 1957. Histochemical demonstration of enzymes separated by zone electrophoresis in starch gel. Science, N.Y., 125:1294-1295.

MOORE, G. S.; PETERS, H. A. \& LEVIN, R. E. 1970. Alterations in the electrophoretic patterns of refrigerated fish. J. Fish. Res. Bd Can., 27:31-38.

O'ROURKE, F. J. 1974. Fish. In: Wright, C. A., ed. - Biochemical and immunological taxonomy of animals. London, Academic Press, p.243-302.

PETERSON, G. L. \& SHEHADEH, Z. H. 1971. Subpopulations of the Hawaiian striped mullet Mugil cephalus: analysis of variations of nuclear eye-lens protein electropherograms and nuclear eye-lens weights. Mar. Biol., $11(1): 52-60$.

PHAN, V. N. 1980. Estudo bioquímico e fisiológico sobre os bagres marinhos do Brasil. I. Sobre padrão eletroforético do plasma em gel de poliacrilamida dos bagres da região estuarino lagunar de Cananéia. Bolm Inst. oceanogr., S Paulo, 29(2):301-303. PARDO, W. M. 1977. Micropogon furnieri. II. Estudo dos padrões eletroforéticos de proteinas totais de cristalinos da população I (Cabo Frio - Torres). Ciênc. Cult., S Paulo, 29(7, sup1.):539. Abstract.
SCOPES, R. K. 1968. Methods for starch gel electrophoresis of sarcoplasmic proteins. An investigation of the relative mobilities of the glycolytic enzymes from the muscle of a variety of species. Biochem J., 107:139-150.

SELANDER, R. K. \& JOHNSON, W. E. 1973. Genetic variation among vertebrate species. Ann. Rev. Ecol. Syst., 4: 75-91.

SMITHIES, 0. 1959. An improved procedure for starch-gel electrophoresis: further variation in the serum proteins of normal adults. Biochem. J., 71:585-587.

SUZUKI, H.; VAZZOLER, A. E. A. de M. \& PHAN, V. N. 1983. Estudo eletroforético de proteínas do músculo esquelético de Micropogonias furnieri (Desmarest, 1822) da costa SE-S do Brasil. I. Considerações técnicas. Bolm Inst. oceanogr., S Paulo, 32(2): 153-165.

TSUYUKI, H.; ROBERTS, E. \& VANSTONE, W. E. 1965. Comparative zone electropherograms of muscle myogens and blood hemoglobins of marine and freshwater vertebrates and their application to biochemical systematics. J. Fish. Res. Bd Can., 22 (1) : 203-213.

VAZZOLER, A. E. A. de M. \& PHAN, V. N. 1981. Ocorrência de catarata em Micropogonias furnieri (Desmarest, 1822), na área entre Cabo Frio e Torres $\left(23^{\circ} \mathrm{S}-29^{\circ} \mathrm{S}\right)$, Brasil: investigação de causas e estudo eletroforético das proteínas totais dos cristalinos. Bolm Inst. oceanogr., S Paulo, 30(1):65-76.

ZIGMAN, S. \& YULO, T. 1979. Eye lens ageing in the dogfish (Mustelus canis). Comp. Biochem. Physiol., 63B: 379-385.
(Received 03-Nov-83; accepted 17-Dec-85) 